\title{
Editorial Paper
}

\section{The Process of the Growth of Small and Medium-Sized Enterprises (SMEs)}

\section{Marta Gancarczyk ${ }^{1}$, Jon Mikel Zabala-Iturriagagoitia²}

\section{INTRODUCTION}

Firm growth is a central topic in the literature on entrepreneurship, strategic management and industrial organization, among others. For an individual entrepreneurial firm, growth is an evidence of the return of the entrepreneur's investment and self-fulfillment. Growth is also a condition of survival for young and small businesses, as growing firms are found less vulnerable to failure than non-growers (Stam et al., 2006). The macroeconomic importance of firm expansion was recognized in the 1980s, when the phenomenon of gazelles or high-growth firms was first described as those capable of intense size increases within a limited time span (Birch, 1981; Birch \& Medoff, 1994; Birch et al., 1994; Storey, 1994; Coad, 2009; Acs et al., 2008). According to empirical research gazelles form a small fraction of business population. However, they represent a disproportionally large share in new job creation (Storey, 1994; Coad 2009; Stam et al., 2006; Acs et al., 2008). Growing firms are also more likely to generate innovations, specifically product innovations involving technological advancements (Coad, 2009; Schreyer, 2000; Storey, 1994; Smallbone et al., 1995).

Both researchers and policy makers interested in expansion, focus on rapidly growing firms and on small and medium-sized enterprises. This interest in high-growth enterprises is justified by the observation that the

1 Marta Gancarczyk, Dr. Hab., Jagiellonian University, Institute of Economics, Finance and Management, ul. Prof. S. Łojasiewicza 4, 30-348 Kraków, Poland; marta.gancarczyk@uj.edu.pl. The contribution of Marta Gancarczyk to this article and to the editorial work on the issue "The process of firm growth" (JEMI 11(4) 2015) is a result of the project financed by the Polish National Science Centre (Narodowe Centrum Nauki) - Decision no. DEC-2013/09/B/HS4/0193 2 Jon Mikel Zabala-Iturriagagoitia, Dr., Deusto Business School, University of Deusto. Camino de Mundaiz 50, 200012 Donostia-San Sebastian, Spain; jmzabala@deusto.es. 
remaining population either grows slowly or does not perform any expansion (Coad, 2009). At the same time, gazelles are predominantly young, small and medium-sized enterprises (SMEs). The dynamics and economic contribution of firms' growth are negatively associated with age and size, which corresponds to the observation that job losses are generated mainly by the established, large and non-growth firms (Acs et al., 2008).

As firm expansion and growth have proved to be a condition for competitive advantage both at the level of individual firms and at the level of the economy at large, the phenomenon of firm growth has become a focus of research. One of the main purposes of this increasingly preeminent research stream is to provide recommendations for firm management and for economic policy, undergoing the risks and challenges in achieving expansion. However, in order to provide these recommendations, we need to better comprehend the entrepreneurial motivations and the attitudes towards growth, the stimuli and impediments to company growth, the potential mechanisms to firm growth and modes of expansion.

This special issue seeks to contribute to the knowledge base on the growth process of entrepreneurial firms, which is an emerging stream of research on firm growth. This emerging stream complements the existing perspectives on expansion, which are more focused on: 1) companies' internal adaptation mechanisms, as reflected in life cycle models, and on 2) determinants and predictors of firm growth (Dobbs \& Hamilton, 2006; McKelvie \& Wiklund, 2010). We present the focus provided in this special issue as complementary to existing approaches, aiming also to contribute with new findings in addressing some yet underexplored areas. The emerging stream of growth process refers to why and how growth is implemented through proactive entrepreneurial actions and decision-making processes, which are presented in complex organizational and environmental contexts, including cause-effect mechanisms in the history of company development. This holistic approach is a constituent feature of studies on the growth process. It differentiates from the currently dominating focus on the determinants of individual firm's growth and from the earlier stage models of internal adaptation to the challenges imposed by expansion.

In the following sections of this introductory paper, we discuss first the stream of research on the growth process in connection with the extant literature on firm growth. Then we highlight the contribution of the individual papers included in this special issue as well as the contribution aimed at by the entire issue as a whole. Finally, the conclusion delineates some potential pathways for further research as a result of the findings provided by the special issue. 


\section{THE RESEARCH ON THE FIRM GROWTH PROCESS AND ITS RELATIONSHIPS WITH OTHER PERSPECTIVES ON FIRM EXPANSION}

Studies on firm growth have evolved into a number of approaches, which have in turn addressed various research gaps, questions and problems through the use of differing methodologies (Gilbert et al., 2006; Dobbs \& Hamilton, 2006; Davidsson et al., 2006; McKelvie \& Wiklund, 2010). In particular, in this introductory paper we will focus on three of them.

The first, which refers to the early stream of life cycle models, deals with how to manage a company that has achieved substantial growth (Dobbs \& Hamilton, 2006; McKelvie \& Wiklund, 2010). The numerous models of stage growth, such as those by R. Greiner (1972), R. Scott and R. Bruce (1987), N. Churchill and V. Lewis (1983), assume determinism of some strictly defined phases. However, these approaches do not reflect the reality of irregular and idiosyncratic patterns of firm expansion. Moreover, the critiques of this approach point to a lack of theoretical background and empirical support that would prove validity of the life cycle pattern to organizational development. This approach is still considered useful in scholarly work though, given that it serves more as a framework of development options and scenarios, than as a deterministic vision of firm pathways. Recently, Levie and Lichtenstein (2010) carried an extensive review of growth stage models and proposed their reconceptualization into a 'dynamic states approach', freeing the conception from previous deterministic views, and assuming heterogeneity of firms and idiosyncrasy of their development patterns. This may provide a revitalization of the conception towards more open and situational adaptation of the life cycle framework, where the triple of opportunity recognition, business model, and value increase is regarded a mechanism that explains a firm's specific development stage (Levie \& Lichtenstein, 2010). Overall, life cycle models treat expansion as a challenge to managerial systems, requiring continuous adaptation and transformation, rather than as a desired outcome. This stream is thus built on the management systems and the routines required when dealing with growth by adapting and transforming the internal organization. In other words, it explains how to react to and manage growth, but not how to proactively achieve growth by running specific activities, processes and routines, and how entrepreneurs make decisions and perceive the rationales, mechanisms and modes in implementing the expansion.

Growth as a desired outcome became a focus of the second stream of studies that emerged after the importance of gazelles was identified, particularly for creation of employment and the definition of innovation policies. This currently dominating stream intends to address what are determinants and predictors of firm size escalations, to inform both policy and management practice. One of the main contributions of this group of 
studies lies in the identification of a number of factors correlated with firm expansion, characterizing the entrepreneur, the firm and its strategy, that proved to be significant in the majority of the works (Barringer et al., 2005; Coad, 2009; Moreno \& Casillas, 2007; Gilbert et al., 2006; Macpherson \& Holt, 2007; Storey, 1994). However, uncertainty still remains about the real mechanisms of growth and the cause-effect relationships that may arise during this process, i.e. which factors are growth determinants, and which are only associated to or stimulated by growth (Dobbs \& Hamilton, 2006; Wright \& Stigliani, 2013). Moreover, the meaning and importance of some factors are not fully consistent (Achtenhagen et al., 2010; Dobbs \& Hamilton, 2006). The observed ambiguity is attributed to differing methodologies and measures of expansion adopted in these predominantly quantitative studies (McKelvie \& Wiklund, 2010; Shepherd \& Wiklund, 2009), which requires the conduit of case studies using different approximations and methods, as the papers in this special issue aim at.

Finally, the third new and emerging pathway of research complements and broadens the earlier studies by focusing on the growth process (Davidsson et al., 2006; Leitch et al., 2010; McKelvie \& Wiklund, 2010; Stam, 2010; Dobbs \& Hamilton, 2011; Wright \& Stigliani, 2013; Koryak et al., 2015). It intends to address some under-researched issues by exploring why and how growth is implemented, while assessing entrepreneurs' decision making routines and processes (Wiklund \& Shepherd, 2003; Wiklund et al., 2003; Garnsay et al., 2006; Hansen \& Hamilton, 2011; Wright \& Stigliani, 2013). Relative to the first stream, it seeks to explain proactive decisions and activities in implementing growth, not only following adaptive and reactive strategies. Alternatively to the second stream, it intends to unveil mechanisms and cause-effect relationships among the factors leading to growth, not only the individual success factors. During periods of intense growth, there may be changes and trade-offs in the modes, rationales, motives and mechanisms of company behavior, stemming from the changing characteristics of its resources and the environment in which firms are embedded. These changes can explain differing assumptions and empirical verifications of leading theoretical frameworks on growth, and find inconsistencies or discrepancies with todate research on growth determinants. Such a research focus requires indepth, explorative studies, investigating the phenomenon in specific contexts to explain the entrepreneurs' perceptions, decisional rules and actions. These findings may form new theoretical and empirical approximations, which eventually may require further quantitative studies, such as identifying valid growth determinants.

The research streams we have discussed above have different purposes and concentrate on different problems, providing often complementary 
answers. Besides contributing with specific insights into the growth phenomenon, they also mutually enrich and reinforce one another. Table 1 presents the prospective input from the growth process perspective to other streams and in what way this perspective can draw upon the more established approaches.

Table 1. The research streams in firm growth and the interrelations among these perspectives

\begin{tabular}{|c|c|c|c|}
\hline $\begin{array}{l}\text { Research } \\
\text { stream on firm } \\
\text { growth }\end{array}$ & $\begin{array}{l}\text { Studies on growth } \\
\text { determinants and } \\
\text { predictors }\end{array}$ & $\begin{array}{l}\text { Studies on firms' } \\
\text { internal adaptation } \\
\text { after achieving growth } \\
\text { (stage models) }\end{array}$ & $\begin{array}{l}\text { Studies on growth } \\
\text { process }\end{array}$ \\
\hline $\begin{array}{l}\text { Research } \\
\text { questions }\end{array}$ & What drives growth? & $\begin{array}{l}\text { How to manage a firm } \\
\text { that has accomplished } \\
\text { growth? }\end{array}$ & $\begin{array}{l}\text { Why and how to achieve } \\
\text { growth? }\end{array}$ \\
\hline Outcomes & $\begin{array}{l}\text { Features and factors } \\
\text { correlated with growth, } \\
\text { characteristics of the } \\
\text { entrepreneur, the firm, } \\
\text { and its strategy. }\end{array}$ & $\begin{array}{l}\text { Internal structures and } \\
\text { management systems } \\
\text { that require adaptation. } \\
\text { Suggestions of potential } \\
\text { business models as a } \\
\text { response to opportunity } \\
\text { recognition and the } \\
\text { need to create value. }\end{array}$ & $\begin{array}{l}\text { The entrepreneur's } \\
\text { decisional rules with } \\
\text { regard to motives, } \\
\text { rationales, mechanisms } \\
\text { and modes of growth } \\
\text { in a specific context, } \\
\text { depending on firms' } \\
\text { capabilities and the } \\
\text { environment in which } \\
\text { they are embedded. }\end{array}$ \\
\hline $\begin{array}{l}\text { Underexplored } \\
\text { problems/ } \\
\text { Limitations }\end{array}$ & $\begin{array}{l}\text { Underexplored } \\
\text { mechanisms of } \\
\text { growth (cause-effect } \\
\text { relationships); ambiguity } \\
\text { in some of the } \\
\text { determinants identified } \\
\text { to date. }\end{array}$ & $\begin{array}{l}\text { Underexplored } \\
\text { proactive approaches } \\
\text { to accomplishing } \\
\text { growth; reactive growth } \\
\text { strategies; unrealistic } \\
\text { determinism of stage } \\
\text { models. }\end{array}$ & $\begin{array}{l}\text { A potential limitation } \\
\text { might be the excessive } \\
\text { idiosyncrasy of the } \\
\text { findings, which are } \\
\text { dependent on particular } \\
\text { and complex contexts } \\
\text { that may lead to a } \\
\text { difficult generalization. }\end{array}$ \\
\hline $\begin{array}{l}\text { Can the } \\
\text { streams } \\
\text { benefit one } \\
\text { another? }\end{array}$ & $\begin{array}{l}\text { Can benefit from and } \\
\text { contribute to research } \\
\text { on the firm growth } \\
\text { process by pointing to } \\
\text { drivers of this process. }\end{array}$ & $\begin{array}{l}\text { Can benefit from and } \\
\text { contribute to the studies } \\
\text { on the firm growth } \\
\text { process by showing how } \\
\text { business models need } \\
\text { to change and adapt } \\
\text { to the environment in } \\
\text { response to growth. }\end{array}$ & $\begin{array}{l}\text { Can benefit from } \\
\text { and contribute to } \\
\text { the studies on firms' } \\
\text { growth determinants by } \\
\text { identifying contingencies } \\
\text { under which ambiguous } \\
\text { determinants hold. } \\
\text { Can also contribute } \\
\text { to the studies on the } \\
\text { management of firm } \\
\text { growth by signaling and } \\
\text { assessing how specific } \\
\text { business models (stages) } \\
\text { are created and how } \\
\text { these may foster firm } \\
\text { growth in the different } \\
\text { stages. }\end{array}$ \\
\hline
\end{tabular}


The research on the firm growth process can draw upon the knowledge on growth determinants and on the internal management of a company that achieved growth, as these findings are important inputs into the explanation of why and how expansion is achieved. Conversely, the research on the growth process of firms can benefit the stream on growth determinants by identifying contingencies under which some factors hold and others do not, thus reducing the ambiguity of to-date findings. These contingencies can be explored due to the emphasis of the growth process studies on the contextual issues. The stage models, in turn, can be enriched by the findings on growth process that would show how specific business models are created to foster expansion.

\section{THEORETICAL BACKGROUND OF STUDIES ON THE FIRM GROWTH PROCESS}

The majority of the entrepreneurship research on firm growth applies Penrosian and follows a resource-based view (the RBV) approach. The foundations of firm growth conception were laid by Penrose (1959) and evolutionary economists such as Nelson and Winter (1982). As a result, and in parallel to these contributions, the resource-based approach to decisionmaking on firm scope and size was further developed (Peteraf, 1993; Wernerfelt, 1984; Barney, 1991; Hamel \& Prahalad, 1990; Kogut \& Zander, 1992). Penrose perceived growth as a process of learning and development of capabilities, eventually resulting in scope and size enlargement. Concepts such as core competence and core-related capabilities (Hamel \& Prahalad, 1990), absorptive capacity (Cohen \& Levinthal, 1990; Zahra \& George, 2002) and dynamic capabilities (Teece et al., 1997, Teece, 2007) have comprehensively provided explanatory power with regard to learning and knowledge development that lead to innovative outcomes. The heterogeneity of firm capabilities is thus reflected in the differences in their competitive positions and the ways firms achieve growth.

The RBV logic is applied in the majority of the entrepreneurship studies on growth determinants. These studies focus on the internal characteristics of the entrepreneur, the firm, and its strategy. Similarly, the classical growth stage models adopt an internal focus on firm resources and management systems. In spite of the capability-oriented thinking, the life cycle studies and studies on growth determinants are inductive and empirical rather than deductive and theory-driven. Therefore they rarely apply the core concepts of the RBV, including its developments such as absorptive capacity and dynamic capabilities.

Absorptive capacity (AC) is one of the key concepts that emerges from the understanding of innovation regarding the internal usability of external 
knowledge (Cohen \& Levinthal, 1990). The existing evidence has discussed how companies with good levels of AC are more likely to absorb external knowledge through the establishment of cooperation agreements, what influences the returns these companies get from product and process innovations.

Parallel to the conception of AC, new perspectives on dynamic capabilities have been developed. Dynamic capabilities (DC) are defined as higher level competences that determine the firm's ability to integrate, build, and reconfigure internal and external resources/competences to address, and possibly shape, rapidly changing business environments (Teece et al. 1997; Teece, 2007; Eisenhardt \& Martin 2000; Helfat et al., 2007; Di Stefano et al., 2010). Teece distinguishes between what would actually be organizations' (group) and individuals' routinized behavior, and those DC that fall outside standardized analyses that search for the optimum situation. Teece identifies ordinary capabilities with routines that address repetitive paths over time, which are embedded in organizations and employees and would be imprinted in the algorithms and heuristics of how business organizations carry out and develop their everyday activities. Building on the RBV of the firm, Eisenhardt and Martin (2000) introduce a model that reframes the previous DC approach. The purpose of their model is to know how an organization's competitive edge can be maintained over time.

Considering the nature of $A C$ and $D C$, two assertions can be made as to their relationships with the firm growth process. First, their association with growth, may be captured as a feedback process (results of growth and determinants of growth), as well as direct and indirect influences. Second, the influence of these two constructs on firm growth and expansion needs to be researched in a longer term and continuous perspective rather than focused on some points or limited periods of time.

According to the first assertion, growth is both a result and stimulus of the organization's learning processes, in which both $A C$ and $D C$ play a key role. Moreover, the influences of $A C$ and $D C$ can be described as both direct and indirect. Direct influences can be manifested as a realized AC capacity and as seized opportunities in the DC perspective. The outcomes of firm resources and competences, such as introducing product, process and management innovations (Ahlin et al., 2014; Kotabe et al., 2011) that replace the existing routines and ways of solving problems by more efficient ones are included here (Zollo \&Winter, 2002; Zahra et al., 2006). This evidence of realized AC and seized opportunities (due to DC) directly translates into performance (i.e. employment, sales), and corresponds with a number of findings in the empirical research on growth determinants. The direct influences of $A C$ and DC can be recognized when researching firm behavior in periods of rapid 
growth. The indirect influences are associated with potential AC and the ability to sense the opportunities within the DC perspective, i.e. capabilities that form conditions for absorbing external knowledge and sensing the opportunities to replace existing routines. These are capabilities such as the entrepreneurial orientation and the competence level of management and personnel, which affect growth indirectly and in a long term perspective. The indirect influences of $A C$ and $D C$ do not provide an immediate effect on performance and growth and they can be detected in a longer term perspective that is not limited to the punctuated periods of rapid expansion (Gancarczyk \& Gancarczyk, 2016).

Correspondingly, according to the second assertion, organizational learning can be comprehensively understood with the adoption of longerterm and evolutionary perspectives (Freiling et al., 2012). From this point of view, continuous and incremental development is punctuated by periods of revolutionary change and intense expansion. Therefore, the full nature of capability development would be difficult to capture when focusing on limited time spans of rapid growth only. The empirical evidence within the research on growth determinants focuses mainly on periods of high growth, which may provide limited evidence on the relationships between growth and $A C$ and $D C$ respectively.

The conceptions of AC and DC are focused on how internal capabilities impact the competitive advantage of firms, as moderated by the firm capacity to adapt and change in response to the environment (Gómez-Uranga et al., 2014). Consequently, the nature of growth as a learning process favors casebased, qualitative and in-depth research in the longitudinal perspective. On the other hand, the long-term and learning perspectives on the development of capabilities in response to the environmental challenges and opportunities is also applied in the studies on firm and industry expansion within the literature of evolutionary economics (Nelson \& Winter, 1982), industrial organization (Klepper, 1997, 2007) and organizational ecology (i.e. population ecology of organizations) (Carroll \& Hannan, 2000). In these studies, quantitative approach based on longitudinal data regarding particular industries is adopted to investigate the influence of competitive environment on firm success or failure. This environmental impact on growth prospects is also present in the current conception of entrepreneurial ecosystems (Mason \& Brown, 2014; Isenberg, 2011). However, the entrepreneurial ecosystem scope goes beyond the micro- or industrial environment, and also embraces meso- and macro-environmental components (Dopfer et al., 2004). The systemic approach of entrepreneurial ecosystems was described with a number of models including a variety of components, which may be 
clustered under the labels of actors, resources, institutions, and networks (Fornahl et al., 2015; Gancarczyk, 2015).

This special issue aims at providing new empirical evidence on firm growth, and it can be positioned within a positivist approach in which deductive logic is followed by formulating research questions and hypotheses based on extant theories. The theoretical background of the papers is rooted in the RBV, including AC and DC perspectives, and in the theory of entrepreneurial environment or eco-system. On the other hand, the contributions of this issue are eclectic in implementing this positivist approach. Some studies consequently follow it with the use of quantitative and empirically-oriented methods. Others apply a qualitative and case study methodology, with the use of rich data to be matched with a theoretical background applied. This characteristics link them with the interpretivist method. All the papers, however, are strongly focused on the contextual issues and specificity of actors, places and institutions. Even if as a result some theoretical contributions are obtained, the goal is not to develop new theoretical views or conceptual approaches that fill the current gaps in the literature, but rather to provide new empirical evidence in relation to firm growth processes.

\section{CONTRIBUtions}

The papers included in this special issue add to our understanding on the process of firm growth, using varied methodologies and theoretical approaches, even if the RBV and evolutionary logics dominate. They also contribute to the research on growth determinants and on business models in the firm life cycle. The authors devote a considerable attention to the context of their investigations, presenting both the development pathways of firms and environmental conditions influencing them. Moreover, they consider the time perspective as an important part of that context.

The paper by Claudia D'Annunzio, Mariela Carattoli and Dolores Dupleix (2015) - "Dynamic capabilities associated with a firm's growth in developing countries. A comparative study of Argentinean SMEs in the software and tourism industries" - deepens our understanding related to the concept of DC and firm's growth in the context of developing countries. The study is based on the analysis of eight Argentinean SMEs in the software and tourism industries. It presents a comparative multiple case study focused on the process by which firms develop DC and how these contribute to their growth. The paper aims to shed new light on how SMEs develop capabilities to grow in the specific context of developing countries with resources constraints. The key contribution of the study is that SMEs develop DC mainly through an 
emerging process of iterative experimentation rather than through strategic planning, a process that involves the coordination of organizational actions and resources, and in which firm managers play a key role. Considering the methodology, focus on learning in growth, and on entrepreneurs' perceptions, the paper is positioned within the stream of growth process research.

In line with the previous paper, Andrzej Lis and Agata Sudolska (2015) - "Absorptive capacity and its role for the company growth and competitive advantage: the case of Frauenthal Automotive Torun company" - aim to study the role of AC for firms' growth. In particular, they analyze how DC can lead firms to obtain a relative competitive advantage through open innovations. Through a case study in the Frauenthal Automotive Torun company, the authors explore how the routines and best practices associated with the firm AC contribute to its success. One of the key messages of their paper is that the development of skills and capabilities allows firms to recognize valuable knowledge in the environment, acquire, assimilate, transform and develop it in the form of innovations. The paper adopts an evolutionary, long-term and qualitative method in studying growth, thus corresponding to the research on the process of firms' expansion.

The paper by Urban Pauli (2015) - "In what to invest after surviving the investment structure of growing SMEs" - adopts a life cycle pattern to investigate the structure of investment in SMEs, depending on their phase of growth. The research is based on a quantitative study of 286 Polish SMEs, clustered in various stages, according to the author's model, which emanates from a synthesis of a number of life cycle concepts. The RBV logic is adopted in theoretical background of the study and in seeing growth as conditioned by the appropriate choice of resources to invest in. He also emphasizes performance issues, and finds relationships between the growth stage, the investment structure and the firm's outcomes. These conclusions support the reasoning of a dynamic states approach, as the author is not focused on a predetermined sequence of development for an individual company, but on the choice which resources to develop, depending on the state of the firm. The most important observation is that the entrepreneurs that accomplish high performance adjust their investment structure to the requirements of a specific phase of development, demonstrating responsiveness to the changing context of their businesses. Alternatively, the entrepreneurs featuring minor performance do not change and adjust their investment structure, but rather keep it stable regardless of the growth stage.

The paper by Renata Lisowska (2015) - "External determinants of the development of small and medium-sized enterprises - empirical analysis" - puts emphasis on how the external environment influences SMEs' development and growth. This analysis differentiates by a thorough and 
systematic categorization of specific levels of environment and of the impact of specific factors (barriers and stimulants). The assessment of specific factors was provided by the research sample of 590 SMEs. The author refers to the particular context for her research, both in terms of the object of study and by referring to the extant Polish findings on environmental conditions of SME development. This approach is justified by the complexity of the environment, which allows for generalizability of the findings in the specific conditions of a region or a country. The research belongs to the stream on growth determinants. However, it provides important insights into the entrepreneurial perceptions of the environmental influences in the process of development and growth. The main message is that Polish entrepreneurs perceive their environments in terms of barriers rather than in terms of stimulants. Moreover, the findings are informative for policy and management of SMEs as they point to the main impediments of growth and development as perceived by the entrepreneurs. The study confirms the findings from the earlier Polish research in this area, which evidences the limited or non-existing improvements in shaping the environment by policy makers on the one hand, and similarly, the limited improvement in SMEs' capabilities to face these challenges on the other. In the case of meso- and micro-environments, the sets of barriers and stimulants differ for firms in different size classes. This observation calls for policy measures tailored to micro-, small and medium-sized firms.

The paper by Tuomo Heinonen and Francisco Javier Ortega-Colomer (2015) - "Regenerative medicine as an emergent cluster in Tampere Region" - focuses on clusters as an important element for regional economies. The authors discuss how emergent clusters can be a central means to provide regional economies additional diversification. The paper focuses on regenerative medicine as an example of such emergent clusters. The study contributes to the understanding of emergent cluster development in science-based industries in their embryonic and early stages. The paper starts by describing the main obstacles that might eventually impede the proper development of emergent clusters. It also finds how innovations emerge in the cluster and what the main implications for the territory are. The relevance of the study lies in that in embryonic science-based industries, products and services are new knowledge-based, and therefore require the involvement of the academia as a booster and the driver of the emergent cluster. In line with the conclusions raised in the previous paper by Lisowska, the paper concludes by calling for tailor-made socio-economic policies at the meso-level.

Finally, the paper by Angelo Dossou-Yovo (2015) - "Entrepreneurial growth aspirations and familiarity with economic development organizations: 
evidence from Canadian firms" - intends to add to the research on the association between firm growth and the entrepreneurial ecosystem. Specifically it focuses on the relationships between the entrepreneur's familiarity with the economic development organizations in this system and entrepreneurs' willingness to expand. The logic of this investigation differentiates from to date studies in that the author does not investigate the possible dependence of growth aspirations on the networking with the organizations in the ecosystem. The main research question concerns how growth aspirations affect networking behavior as evidenced by familiarity with business development organizations. Such an approach is founded on the assumption that entrepreneurs who intend to pursue growth search for the adequate resources in the ecosystem and address key actors in this environment. The study is based on a large set of data (1400 companies from the Halifax metropolitan area in Canada) obtained in the four-wave survey in years 2011-2013. It offers various implications for entrepreneurs seeking growth, and for policy-makers and providers of business support services who can better recognize their target groups, needs and motivations. Summing up, the findings confirm that the entrepreneurs who intend to expand are more inclined to have networking links with business support organizations than those who do not intend to grow. This insight adds to the research on planning and managing growth and on the sources of knowledge and capital in this process.

The table below provides a short illustration of the main results of the papers in the special issue, emphasizing how each of them can also contribute to the different streams on the growth processes identified in Table 1.

The papers in this issue are positioned in different research streams on entrepreneurial growth. However, all of them contribute to the related streams. As it was indicated in Table 1, their input into the studies on growth process includes the identification of resources and management systems conducive for the pursuit of expansion, the roles of specific actors such as entrepreneurs, managers, employees and business environment organizations, and describing the role of the context at the regional and country levels. Moreover, the papers broaden our understanding of the entrepreneurs' motivations for growth and the mechanisms through which they achieve it. 
Table 2. Contributions of the papers in the special issue to the research streams on firm growth

\begin{tabular}{|c|c|c|}
\hline $\begin{array}{l}\text { Research } \\
\text { stream on } \\
\text { firm growth }\end{array}$ & $\begin{array}{l}\text { Studies on growth } \\
\text { determinants and } \\
\text { predictors }\end{array}$ & $\begin{array}{l}\text { Studies on firms' } \\
\text { internal adaptation after } \\
\text { achieving growth (stage } \\
\text { models) }\end{array}$ \\
\hline $\begin{array}{l}\text { D'Annunzio } \\
\text { et al., } 2015\end{array}$ & $\begin{array}{l}\text { The role of dynamic } \\
\text { capabilities in firm } \\
\text { growth. }\end{array}$ & $\begin{array}{l}\text { Dynamic capabilities and } \\
\text { the phases of strategy } \\
\text { development and } \\
\text { execution. }\end{array}$ \\
\hline $\begin{array}{l}\text { Lis \& } \\
\text { Sudolska, } \\
2015\end{array}$ & $\begin{array}{l}\text { Role of absorptive } \\
\text { capacity and } \\
\text { open innovation } \\
\text { for firms' growth } \\
\text { and competitive } \\
\text { advantage. }\end{array}$ & $\begin{array}{l}\text { Firms need to recognize } \\
\text { valuable knowledge } \\
\text { in the environment, } \\
\text { acquire, assimilate, } \\
\text { transform and develop/ } \\
\text { exploit it to benefit from } \\
\text { open innovation. } \\
\text { Routines, lessons } \\
\text { and best practices in } \\
\text { absorptive capacity. } \\
\text { Absorptive capacity as a } \\
\text { process. }\end{array}$ \\
\hline Pauli, 2015 & $\begin{array}{l}\text { Proactive } \\
\text { investment behavior } \\
\text { associated with firm } \\
\text { performance. }\end{array}$ & $\begin{array}{l}\text { Growth firms need to } \\
\text { adapt their investment } \\
\text { decisions to specific } \\
\text { requirements of the life } \\
\text { cycle stages. }\end{array}$ \\
\hline
\end{tabular}

$\begin{array}{ll}\text { Lisowska, } & \text { Identification } \\ 2015 & \text { of barriers and }\end{array}$ 2015 stimulants of SME

development and

growth at the micro-,

meso- and macro-

environmental levels.

Benchmark for other

studies performing

a systematic analysis

of the levels of

the environmental

influences in other

contexts of time and

place.

\section{Studies on growth process}

Capacities to learn, sense, filter, shape and calibrate opportunities.

Structures, procedures, designs and incentives for seizing opportunities. Firm growth as an outcome of absorbing and utilizing new knowledge.

Importance of executives and employees' learning from external sources.

Small steps towards novelty.

The entrepreneurs that achieve high performance monitor their capabilities and external challenges in the process of growth and they differentiate the investment structure in particular resources according to their specific needs.

An integrative model of firm growth stages is offered.

Barriers and stimulants The findings are informative of firm development of entrepreneurs pursuing arising from micro- and their growth in the Polish meso-environments context.

differ depending on SME The set of barriers and size. stimulants as a guidance for the entrepreneurs to pursue their own growth strategies and as a framework for researchers to be tested in the specific process of firm growth. The factors of SME development and growth describe the entrepreneurial ecosystem in Poland regarding its actors, resources, and activities. 


\begin{tabular}{|c|c|c|c|}
\hline $\begin{array}{l}\text { Research } \\
\text { stream on } \\
\text { firm growth }\end{array}$ & $\begin{array}{l}\text { Studies on growth } \\
\text { determinants and } \\
\text { predictors }\end{array}$ & $\begin{array}{l}\text { Studies on firms' } \\
\text { internal adaptation after } \\
\text { achieving growth (stage } \\
\text { models) }\end{array}$ & Studies on growth process \\
\hline $\begin{array}{l}\text { Heinonen } \\
\text { \& Ortega- } \\
\text { Colomer, } \\
2015\end{array}$ & $\begin{array}{l}\text { Identification of } \\
\text { obstacles eventually } \\
\text { impeding the proper } \\
\text { development of } \\
\text { emergent clusters in } \\
\text { their embryonic and } \\
\text { early stages. } \\
\text { Competence bloc } \\
\text { theory can allow } \\
\text { the evaluation } \\
\text { of the required } \\
\text { competencies for } \\
\text { economic growth } \\
\text { and successful } \\
\text { innovations from } \\
\text { both a business and } \\
\text { innovation point of } \\
\text { view. }\end{array}$ & $\begin{array}{l}\text { Cluster life cycle theory } \\
\text { can be reinforced by } \\
\text { focusing attention on the } \\
\text { commercial engine that } \\
\text { enables growth of firms. } \\
\text { Firms in emergent } \\
\text { science-based clusters } \\
\text { are dependent on the } \\
\text { knowledge generated } \\
\text { within academic actors. }\end{array}$ & $\begin{array}{l}\text { Emergent clusters are } \\
\text { important for regional } \\
\text { economies. } \\
\text { Tailor-made socio-economic } \\
\text { policies at the meso-level } \\
\text { are required to guarantee } \\
\text { the survival and further } \\
\text { development of emergent } \\
\text { clusters and the firms within. }\end{array}$ \\
\hline $\begin{array}{l}\text { Dossou- } \\
\text { Yovo, } 2015\end{array}$ & $\begin{array}{l}\text { Familiarity } \\
\text { with economic } \\
\text { development } \\
\text { organizations } \\
\text { associated with } \\
\text { growth aspirations. }\end{array}$ & $\begin{array}{l}\text { When planning for } \\
\text { growth, companies } \\
\text { actively establish links } \\
\text { with actors in the } \\
\text { ecosystems to build } \\
\text { the internal resources } \\
\text { needed for expansion. }\end{array}$ & $\begin{array}{l}\text { Contributes to understanding } \\
\text { of growth aspirations as } \\
\text { motives for networking with } \\
\text { actors in entrepreneurial } \\
\text { ecosystem. } \\
\text { Suggests mechanisms of } \\
\text { resource acquisition from the } \\
\text { ecosystem as conducive for } \\
\text { growth. }\end{array}$ \\
\hline
\end{tabular}

\section{FURTHER RESEARCH}

This section aims to provide a short discussion of the main gaps identified by the group of papers included in the special issue. With it, we aim to open potential further research paths that may enlighten the different streams of the literature discussed above. Moreover, we can state that the papers suggest theoretical and practical implications regarding two issues associated with the growth process of firms, namely 1 ) entrepreneurial ecosystems and 2) learning and capability development.

In their paper, D'Annunzio et al. find that for entrepreneurs, it is essential to understand the business ecosystem they are embedded it. On the one hand, the ecosystem is what provides them with the necessary contacts to gain access to the knowledge they need (e.g. identifying other entrepreneurs, getting to know their entrepreneurial orientation, making personal and professional contacts, getting involved in other networks). On the other, it also provides entrepreneurs the abilities and experience to make strategic decisions. Thus, it would be required to gain new knowledge and 
understanding on the dynamics of business ecosystems, how these emerge, evolve and shape not only the dynamics of the actors within but also have the ability to shape other related ecosystems. Increasingly, and particularly in recent years, we are witnessing an increasing attention to the meaning and the implications (both in managerial and in policy terms) of business ecosystems. A new literature is emerging in this regard, and thus, more contributions are needed, in relation to entrepreneurial business ecosystems, and the role trust and social networks play in these.

Heinonen and Ortega-Colomer are also in support of new research paths that may shed new light on the support of pro-innovative thinking systems, such as emerging clusters in science-based industries, though new clusters need not necessarily be limited to these. In this sense, the authors provide a number of dimensions that can help these new clusters or ecosystems to consolidate: have certain unique competences that may create the necessary incentives to attract and keep keystone organizations, availability of a network of support (i.e. service of manufacturing) firms, entrepreneurs and venture capital organizations, long-term commitment and support by public bodies, effective knowledge transfer mechanisms being in place, having (internally) or gaining access to (external) demand so that firms can scale-up and further advance their production, providing access to experiences knowledge on intellectual property rights and their management, etc.

Lisowska identifies the barriers and stimulants to SME development in Poland, which can be treated as characteristics of the entrepreneurial ecosystem at the country level. This research points to the key components of this ecosystem, including macroeconomic trends and regulations, meso-, and micro- or competitive environment influences, as perceived by the entrepreneurs. The findings are informative for entrepreneurs and for policy purposes in researching the specific context for SME growth and development in terms of environmental conditions in a specific period of time. It calls for further research to monitor the trends and changes in the sets of determinants and their evaluation by entrepreneurs. Another opportunity for further research is to identify the differences in the entrepreneurs' perceptions of the environment depending on the stage of development (such as growing, mature or declining businesses). This matching approach would provide a more nuanced picture of the environmental challenges for growers versus non-growers.

The research by Dossou-Yovo points to the importance of the resources in business ecosystems for the entrepreneurs who intend to grow. The results prove that potential growers are active in networking with the organizations offering public support in knowledge and capital acquisition. The extant research provides the evidence of networking as one of the success factors, 
i.e. stimuli for growth. This research offers another observation, namely that networking is also a result of the entrepreneurs' intentions to grow, as they actively search for the resources in their ecosystems. There are many potential areas of future investigation that arise from the current findings. Among others, they refer to the role of networking and network management in pursuing growth, to the association between the type of actors in the ecosystems and the specific challenges and stages in the growth process. Another area for further studies refers to policy issues, such as the types of measures and the types of business support organizations that are important for firms that plan and implement growth. These potential results may inform policies directed at developing entrepreneurial ecosystems in terms of the actors and the resources that are central in achieving firms' growth.

There are several manuscripts in the special issue which revolve around the concept of capabilities, including AC and DC and the implications these can have both and the level of individuals and firms. As D'Annunzio et al. discuss, at the startup stage, firms are based mainly on entrepreneurs' skills. Thus, a better understanding of entrepreneurs' managerial skills is required, particularly in the context of young firms, in which individual capabilities are extremely important for their further survival and growth. This further need is in line with the findings by Teece (2007) who also concludes that the ability to recognize opportunities is to a large extent dependent on the capabilities of individuals. This further research on DC is however also linked to the previous one on business ecosystems. In fact, if firms are to grow, these need to continuously identify and weigh the opportunities and changing conditions that may arise not only from the environment in which the firms may operate (Gómez-Uranga et al., 2014), but also from those in related markets (Frenken et al., 2007). Thus, entrepreneurs need to be constantly revising and developing their own entrepreneurial capabilities and those of their firms in order to seek for an effective way to guarantee adaptation to the new environmental contexts, what in turn also has clear managerial implications in terms of the need to restructure existing resources and organizational structures as firms grow and environments change.

The case study conducted by Lis and Sudolska links the concepts of $\mathrm{AC}$ and open innovation, as two central concepts for company growth and competitive advantage. In this sense, further research could be oriented to provider larger evidence of the DC approach discussed above with these two concepts. However, Lis and Sudolska are among the few scholars who provide not only evidence of the benefits of AC for firm growth and adaptation, but also consider it to be process that can be managed. In this sense, they distinguish the following stages into the AC process: knowledge recognition, acquisition, assimilation, transformation and exploitation. Thus, further 
evidence is required on the dynamics and challenges faced by firms, not only in seeking for a larger AC, but also in the management of AC as a process. As Lis and Sudolska discuss, one of the most significant challenges in this regard is related to the mentality of managers and employees. We consider that further research is also here required in relation to the awareness of executes and employees as to AC development, and the introduction of proinnovative thinking systems and pro-innovative behaviors in a large variety of environments and organizational forms, not only firms. Such knowledge may foster and enable all types of organizations (e.g. universities, hospital, public agencies, etc.) to intentionally create conditions that may favor the acquisition, transformation and exploitation of external knowledge.

Urban Pauli provides evidence that high performing SMEs conduct a proactive strategy in pursuing particular resources rather than others, by changing the investment structure depending on the development stage of their businesses. This represents an important insight into the firm growth process by showing how to implement expansion. This differing investment policy denotes both efficiency considerations and sensitivity to changing needs of the business in response to internal and external challenges. Such a behavior may be an evidence of DC to act, i.e. the entrepreneurs adjust and reconfigure their resources as they sense and seize environmental opportunities to establish a competitive advantage. Further research might explore the association between the investment in particular resources and the conception of DC. Moreover, the current findings inspired Pauli to pose additional research themes, such as the influence of industrial and other characteristics of SMEs on the structure of investment in particular resources. Another option for extending the research is to replicate it in the long-term context, to see how the type of resources pursued in specific life cycle phases affects the entire evolution of individual companies and their performance.

\section{References}

Achtenhagen, L., Naldi, L. \& Melin, L. (2010). Business growth-do practitioners and scholars really talk about the same thing? Entrepreneurship Theory and Practice, 34(2). 289-316.

Acs, Z., Parsons, W. \& Tracy, S. (2008). High-impact firms: gazelles revisited. Washington: Small Business Administration.

Ahlin, B., Drnovšek, M. \& Hisrich R.D. (2014). Exploring the moderating effects of absorptive capacity on the relationships between social networks and innovation. Journal for East European Management Studies, 19(2), 213235.

Barney, J. (1991). Firm resources and sustained competitive advantage. Journal of Management, 17(1), 99-120. 
Barringer, B., Jones, F. \& Neubaum, D. (2005). A quantitative content analysis of the characteristics of rapid-growth firms and their founders. Journal of Business Venturing, 20(5), 663-687.

Birch, D. (1981). Who creates jobs? The public interest, 65, 3-14.

Birch, D., Haggerty, A. \& Parsons W. (1994), Corporate almanac, Minnesota: Connetics Inc.

Birch, D. \& Medoff, J. (1994). Gazelles. In Solmon, L. \& Levenson, A. (eds.), Labor markets, employment policy and job creation. Boulder: Westview Press, 159-168.

Carroll, G.R. \& Hannan M.T. (2000). The demography of corporations and industries. Princeton, NJ: Princeton University Press.

Churchill, N.C. \& Lewis, V. (1983). The five stages of small business growth. Harvard Business Review, 61, 30-50.

Coad, A. (2009). The growth of firms: a survey of theories and empirical evidence. Cheltenham: Edward Elgar.

Cohen, W. \& Levinthal, D. (1990), Absorptive capacity: a new perspective on learning and innovation. Administrative Sciences Quarterly, 35(1), 128152.

D’Annunzio, C., Carattoli, M. \& Dupleix, D. (2015). Dynamic capabilities associated with a firm's growth in developing countries. A comparative study of Argentinean SMEs in the software and tourism industries. Journal of Entrepreneurship, Management and Innovation, 11(4), doi: $10.7341 / 20151142$.

Davidsson, P., Delmar, F. \& Wiklund, J. (2006). Entrepreneurship and the growth of firms. Cheltenham: Edward Elgar.

Di Stefano, G., Peteraf, M. \& Verona, G. (2010). Dynamic capabilities deconstructed. A bibliographic investigation into the origins, development and future directions of the research domain. Industrial and Corporate Change, 19(4), 1187-1204.

Dossou-Yovo, A. (2015). Entrepreneurial growth aspirations and familiarity with economic development organizations: evidence from Canadian firms. Journal of Entrepreneurship, Management and Innovation, 11(4), doi: $10.7341 / 20151147$.

Dobbs, M. \& Hamilton, R.T. (2007). Small business growth: recent evidence and new directions. International Journal of Entrepreneurial Behaviour \& Research, 13(5), 296-296.

Dopfer, K., Foster, J. \& Potts, J. (2004). Micro-meso-macro. Journal of Evolutionary Economics, 14, 263-279.

Eisenhardt, K.M. \& Martin, J.A. (2000). Dynamic capabilities: what are they? Strategic Management Journal, 21, 1105-1111.

Fornahl, D., Hassink, R. \& Menzel M.P. (2015) Broadening our knowledge on cluster evolution, European Planning Studies, 23(10), 1921-1931.

Freiling, J., Wassermann, R.M. \& Laudien, S. M. (2012). The broken product chain: rapid paths of service internationalization in terms of the servicedominant logic. Service Industries Journal, 32(10), 1623-1635. 
Frenken, K., Van Oort, A., \& Verburg, T. (2007) Related variety, unrelated variety and regional economic growth. Regional Studies, 41(5), 685-697.

Gancarczyk, M. 2015. Enterprise- and industry-level drivers of cluster evolution and their outcomes for clusters in developed and less developed countries. European Planning Studies, 23(10), 1932-1952.

Gancarczyk, M. \& Gancarczyk, J. (2016). SME supplier upgrading in the cooperation life cycle -evidence from Central and Eastern Europe. Journal for East European Management Studies, 21(4), DOI 10.1688/ JEEMS-2016-Gancarczyk (forthcoming).

Garnsey, E., Stam, E. \& Heffernan, P. (2006). New firm growth: exploring processes and paths. Industry and Innovation, 13(1), 1-20.

Gilbert, B., McDougall, P. \& Audretsch, D. (2006). New venture growth: a review and extension. Journal of Management 32(6), 926-926.

Gómez-Uranga, M., Miguel, J.C., \& Zabala-Iturriagagoitia, J.M. (2014). Epigenetic economic dynamics: the evolution of big internet business ecosystems, evidence for patents. Technovation, 34(3), 177-189.

Greiner, L. (1972). Evolution and revolution as organizations grow. Harvard Business Review, 50, 37-46.

Hamel, G., Prahalad, C. (1990). The core competence of corporation. Harvard Business Review, 68(5-6), 600-620.

Hansen, B. \& Hamilton, R.T. (2011). Factors distinguishing small firm growers and non-growers. International Small Business Journal, 29(3), 278-294.

Heinonen, T. \& Ortega-Colomer, F.J. (2015). Regenerative medicine as an emergent cluster in Tampere Region. Journal of Entrepreneurship, Management and Innovation, 11(4), doi: 10.7341/20151146.

Helfat, C. E., Finkelstein, S., Mitchell, W., Peteraf, M., Singh, H., Teece, D.J. \& Winter, S. (2007). Dynamic capabilities: understanding strategic change in organizations. Malden, MA: Blackwell.

Isenberg, D. (2011). The entrepreneurship ecosystem strategy as a new paradigm for economy policy: principles for cultivating entrepreneurship. Babson Entrepreneurship Ecosystem Project. Babson Park, MA: Babson College.

Klepper, S. (1997). Industry life cycles. Industrial and Corporate Change, 6(1), 145-182.

Klepper, S. (2007). Disagreements, spinoffs, and the evolution of Detroit as the capital of the U.S. automobile industry. Management Science, 53(4), 616-631.

Kogut, B., Zander, U. (1992). Knowledge of the Firm, Combinative Capabilities, and the Replication of Technology, Organization Science, 3(3), 383-397.

Koryak, O., Mole, K., Lockett, A., Hayton, J., Ucbasaran, D., Hodgkinson, G. (2015). Entrepreneurial leadership, capabilities and firm growth. International Small Business Journal, 33, 89-105.

Kotabe, M., Jiang, C. X. \& Murray, J. Y. (2011). Managerial ties, knowledge acquisition, realized absorptive capacity and new product market 
performance of emerging multinational companies: a case of China. Journal of World Business, 46(2), 166-176.

Leitch, C., Hill, F. \& Neergaard, H. (2010). Entrepreneurial and business growth and the quest for a comprehensive theory: tilting at windmills? Entrepreneurship Theory and Practice, 34(2), 249-260.

Levie, J. \& Lichtenstein, B. (2010). A Terminal assessment of stages theory: introducing a dynamic states approach to entrepreneurship, Entrepreneurship Theory and Practice, 34(2): 317-350.

Lis, A. \& Sudolska, A. (2015). Absorptive capacity and its role for the company growth and competitive advantage: the case of Frauenthal Automotive Toruń company. Journal of Entrepreneurship, Management and Innovation, 11(4), doi: 10.7341/20151143.

Lisowska, R. (2015). External determinants of the development of small and medium-sized enterprises - empirical analysis. Journal of Entrepreneurship, Management and Innovation, 11(4), doi: $10.7341 / 20151145$.

Macpherson, A. \& Holt, R. (2007). Knowledge, learning and small firm growth: a systematic review of the evidence. Research Policy, 36(2), 172-192.

Mason, C. \& Brown, R. (2014). Entrepreneurial ecosystems and growth oriented entrepreneurship. Hague, Netherlands: OECD.

McKelvie, A. \& Wiklund, J. (2010). Advancing firm growth research: a focus on growth mode instead of growth rate. Entrepreneurship Theory and Practice, 34(2), 261-288.

Moreno, A., Casillas, J. (2007). High-growth SMEs versus non-highgrowth SMEs: a discriminant analysis. Entrepreneurship and Regional Development, 9(1), 1-30.

Nelson, R. \& Winter, S. (1982). An evolutionary theory of economic change. Cambridge: Harvard University Press.

Pauli, U. (2015). In what to invest after surviving - the investment structure of growing SMEs. Journal of Entrepreneurship, Management and Innovation, 11(4), doi: 10.7341/20151144.

Penrose, E. (1959). The theory of the growth of the firm. Oxford: Oxford University Press.

Peteraf, M. (1993). The cornerstones of competitive advantage: a resourcesbased view.

Strategic Management Journal, 14(3), 179-191.

Schreyer, P. (2000), High-growth firms and employment, OECD Science, Technology and Industry Working Papers, No. 2000/03, OECD Publishing, Paris.

DOI: http://dx.doi.org/10.1787/861275538813

Scott, B.R. \& Bruce, R. (1987). Five stages of growth in small business. Long Range Planning, 20(3), 45-52.

Shepherd, D. \& Wiklund, J. (2009). Are we comparing apples with apples or apples with oranges? Appropriateness of knowledge accumulation 
across growth studies. Entrepreneurship Theory and Practice, 33(1), 105123.

Smallbone, D., Leigh, R. \& North, D. (1995). The characteristics and strategies of high-growth SMEs. International Journal of Entrepreneurial Behavior \& Research, 1(3), 44-62.

Stam, E., Suddle, K., Hessels, J. \& Von Stel, A. (2006). High-growth entrepreneurs, public policies and economic growth. EIM Business \& Policy Research; SCALES Scientific Analysis of Entrepreneurship and SMEs: Zoetermeer.

Stam, E. (2010). Growth beyond Gibrat: firm growth processes and strategies. Small Business Economics, 35(2), 129-135.

Storey, D. (1994). Understanding the small business sector. London: Routledge.

Teece, D. (2007), Explicating dynamic capabilities: the nature and microfoundations of (sustainable) enterprise performance. Strategic Management Journal, 28(13), 1319-1350.

Teece, D., Pisano G. \& Shuen, A. (1997). The dynamic capabilities of firms: an introduction. Industrial and Corporate Change, 3(3), 537-556.

Tsang, E. (2000). Transaction cost and resource-based explanations of joint ventures: a comparison and synthesis. Organization Studies, 21(1), 215242.

Wernerfelt, B. (1984). A resource-based view of the firm. Strategic Management Journal, 5(2), 171-180.

Wiklund, J. \& Shepherd, D. (2003). Aspiring for, and achieving growth: the moderating role of resources and opportunities. The Journal of Management Studies, 40(8), 1919-1941.

Wiklund, J., Davidsson, P. \& Delmar, F. (2003). What do they think and feel about growth? An expectancy-value approach to small business managers' attitudes toward growth. Entrepreneurship Theory and Practice, 18(3), 247-270.

Wright, M. \& Stigliani, I. (2013). Entrepreneurship and growth. International Small Business Journal, 31(1), 3-22.

Zahra, S. \& George, G. (2002). Absorptive capacity: a review, reconceptualization, and extension. Academy of Management, 27(2), 185-203.

Zahra, S.A., Sapienza, H.J. \& Davidsson, P. (2006). Entrepreneurship and dynamic capabilities: a review, model and research agenda. Journal of Management Studies, 43(4), 917-955.

Zollo, M. \& Winter, S. (2002). Deliberate learning and the evolution of dynamic capabilities. Organization Science, 13(3), 339-351. 


\section{Biographical notes}

Marta Gancarczyk is an Associate Professor at the Institute of Economics, Finance and Management, Jagiellonian University in Krakow, Poland. Her research, publication and consulting activities focus on entrepreneurship, firm growth, technology management and commercialisation, industrial clusters, and public policy for small and medium-sized enterprises. She is involved in consulting for public agencies in the area of SME support measures and in the Council of the Polish Cluster of Innovative Enterprises.

Jon Mikel Zabala-Iturriagagoitia is lecturer at the University of Deusto in San Sebastian, Spain. He was previously Assistant Professor at the Centre for Innovation, Research and Competence in the Learning Economy (CIRCLE), Lund University (Sweden). His research and teaching interests are related to the fields of innovation policy and innovation management. He has been engaged in courses at the Ph.D., Master's degree and undergraduate levels at several European and Latin American universities. 